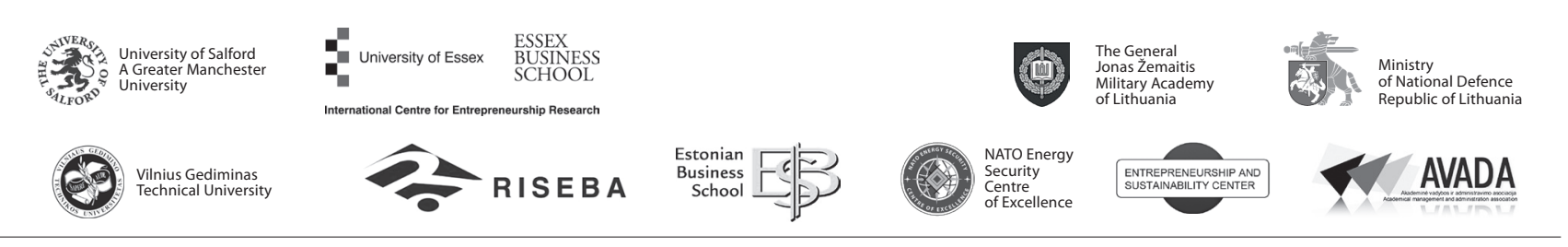

\author{
JOURNAL OF SECURITY AND SUSTAINABILITY ISSUES \\ ISSN 2029-7017 print/ISSN 2029-7025 online \\ 2018 June Volume 7 Number 4 \\ https://doi.org/10.9770/jssi.2018.7.4(22)
}

\title{
TOWARDS SUSTAINABILITY: BUSINESS TO BUSINESS SEGMENTATION IN CARDBOARD MARKET
}

\author{
Vladimír Kubeš ${ }^{1,2}$, Stanislava Grosová ${ }^{3}$, Pavel Weber $^{4}$ \\ 1,3,4 University of Chemistry and Technology in Prague, Technická 5, Praha 6, Czech Republic \\ ${ }^{2}$ INTERLIGNUM a.s., Koželužská 157, 58301 Chotěboř, Czech Republic \\ E-mails: ${ }^{1}$ kubes@intermont-nabytek.cz, ${ }^{2}$ grosovas@vscht.cz, ${ }^{3}$ pavel.weber@vscht.cz
}

Received 20 January 2018; accepted 17 March 2018

\begin{abstract}
Sustainable development is affected by packaging. This article deals with the market segmentation and its implementation in the specific market for secondary cardboard packaging. The research was carried out in order to determine segments based on business customers' needs, demands and characteristics. Customer needs and requirements on corrugated cardboard were formulated by personal questioning of key account managers of cardboard producing companies and marketing, purchasing and logistic department employees from companies. Ten requirements on product attributes and ten requirements on supplier services was identified. The importance of attributes was determined on the 100 points constant sum scale for both groups of requirements. Data were gathered by an on-line questioning, mail was sent to 73228 respondents, who were acquired from database Albertina database according to economic activities classification (CZ-NACE). Companies, who have at least one listed economic activity corresponding to any of FEFCO sectors were chosen. Total of 848 completed questionnaires were collected. IBM SPSS Statistics 19, principal component analysis and cluster analyses was used in the identification and description of segments and their profiles. Based on results of segmentation process, proposed strategies were identified. This is a follow-up study of the research carried out in 2010. Aside from the significant broadening the respondent base by including small and medium-sized companies, results of this research can be easily implemented in targeting new customers and in determining value proposition in segments.
\end{abstract}

Keywords: sustainability of performance; business to business market segmentation; secondary packaging; buying behavior; marketing, purchasing

References to this paper should be made as follows: Kubeš, V.; Grosová, S.; Weber, P.; 2018. Towards sutainability of performance: business to business segmentation in cardboard market, Journal of Security and Sustainability Issues 7(4): 869-882.

https://doi.org/10.9770/jssi.2018.7.4(22)

JEL Classifications: M29, L19

\section{Introduction}

Packaging has become an importact factor affecting sustainable development processes and is widely discussed (Oganisjana et al., 2017; Fabuš, 2017; Ślusarczyk, Kot, 2018). The cardboard industry is one of the important packaging segments. In Europe the volume of produced cardboard sustainably grew until 2015 and reached 43,238 millions $\mathrm{m}^{2}$. The decline of industrial production during economical crisis in 2008-2010 meant almost $5 \%$ shrinking especially as a result of lowered amount of transported goods. The decisive share, over $40 \%$ of corrugated cardboard are processed at the transport and handling package.

There is a long lasting trend of package tailoring and individual customer servicing in the corrugated cardboard package branch. The corrugated cardboard market research was carried out in 2010 (Grosová, Gros, Císařová, 
2011) in order to verify the possibility of business to bussiness (B2B) market segmentation. The aim was to find the typical segments of this industrial packaging market as the basis for the implementation of differentiated strategies. The research focused mainly on existing, partly on the potential customers.

The 2010 research was carried out by personal and electronic questioning. From the total of 554 companies asked, 226 replied, out of which 126 companies did not use corrugated cardboard and 100 filled in complete questionnaire. Most of them, 91 were existing customers. Most important findings were:

1. The requirements for corrugated cardboard. Respondents evaluated the significance of packaging attributes with constant -sum scale 100 points allocation (Aaker, 2003). As the most important was evaluated price with 45.2 points, then quality with 27.3 points, convenience of handling with 14.1 points, environmental impact with 8.2 points, surfacing with 2.7 points, originality with 2.1 points, and the remaining 0.7 points were attributed to other factors.

2. The required level of service. Those, who answered rated the frequency of deliveries required. In $27 \%$ of respondents orders are preferred weekly, in $21 \%$ monthly, in $16 \%$ four times in one year, but $7 \%$ prefers daily delivery. There is also an apparent reluctance to make orders for a longer period. Nearly $70 \%$ of respondents required delivery date 5 days or less, $28 \%$ of respondents expected deliveries within 48 hours. Answers to the question concerning the optimal size of orders is difficult to assess because it depends on many factors, e.g. on delivery frequency. Yet $30 \%$ of respondents considered the optimum size of the order of $35 \%$ up to 1,000 units, $30 \% 1000$ to 5000 units and 35\% of respondents requires from 5000 to 30000 units.

3. The issue of selecting and collaboration with packaging suppliers. The most important selection criteria include reliability (25.4), delivery time (20.8), flexibility in the delivery time (16.2) and payment of invoices (10.1).

4. In the supplementary questions respondents reported some characteristics of their buying decision centers. In the issue of centralization degree of the buying process $38 \%$ respondents reported buying center centralization on domestic or international level, 38\% consists from one organisation unit with buying center and the rest $24 \%$ respondents has autonomous buying center in every organization unit. $55 \%$ of respondents do not close long term contracts with suppliers, only $7 \%$ of respondents makes the contracts on more than one year and only $38 \%$ close contracts with suppliers for the period up to one year. Most of the respondents, almost $50 \%$, does not require consultation service on packaging design and has no interest in cooperation in this area. $36 \%$ of them consult only their own required changes in design. With regards to who makes decisions, in majority of companies it is one person; this person in 50\% of cases comes from the purchasing or logistics department and in $13 \%$ of cases it is somebody from the production personnel.

In the 2010 research answers from companies with over than 3 billion CZK turnover were excluded from Principal Component Analysis and cluster analyses due to their unique needs and characteristics. These were the three companies which were classified as extra large companies in the general characteristic. After excluding the three companies, four segments were identified:

\section{Segment 1 - "Followers of world trends"}

The name comes from the fact that the described behavior corresponds to the world trends. Respondents in this segment tend to the position of "ecology first" and "user-friendly packaging". They are therefore willing to pay more for environmentally friendly packaging which allows easy manipulation. The factor "Anytime at a reasonable price" reaches strong negative values, which can be explained as the willingness to accept less flexibility in delivery times. Variations of all these factors is huge, probably the segment also includes companies that do not always decide in the same way.

\section{Segment 2 - "Unassuming consumers"}

This group is defined primarily by negative values in the tendency to "user-friendly packaging", "big and independent" and "ecology first". Thus, it is rather a medium-sized business, according to classification (European Commission, SME classification), that requires standard packages without much added value. This is supported by a positive factor score "normal requirements". 
Segment 3 - "Planning customers"

In this case, decisive factors are "Ordering" and "Anytime at a reasonable price". Enterprises in this segment seek long-term reliability of linked contracts and fast delivery in the case of an unexpected situation. Through long term contracts with supplier they seek to secure a good price.

Segment 4 - "The occasional buyers"

The fourth segment was the smallest (12,7\% of respondents) and was composed almost from SME with yearly turnover below $10 \mathrm{mil}$. Eu. In comparison with other segments is the price the most important buying decision factor. That businesses are light users of corrugated cardboard packaging, they are reluctant to attach a long-term contract and prefer the contract with long payment time.

\section{Extra large companies}

This group is not a segment in its true meaning. Since these companies were excluded, they did not appear in the results of the cluster analysis. Only three companies belong to this group, it is complicated to determine the group characteristics. But there are some attributes that these companies have in common, they are connected by the type of products packaged. All three companies use corrugated cardboard packaging for machinery or electrical equipment and appliances. As with the others, the price is the very important factor in packaging choice. They make long term contracts with their suppliers. They buy over 20 types of packaging and demand them to be delivered daily with lead time of 48 hours. They use corrugated packaging mostly as transport packaging, with the corrugated cardboard share of $26-50 \%$ on total packaging amount.

Due to the limited respondent and company portfolio, whose answers were included in the PCA and following cluster analysis, we considered the results only as a pilot study for a larger scale research. The larger scale research was carried out in 2015. While it is possible to observe increased usage of market segmentation in the Czech B2B market, it still does not match the level in the consumer market. There is little written about the Czech B2B market segmentation, the few authors who wrote about it are only Koudelka (1997), Lošt'áková (2005) and Žáček (2010).

The aims of this paper are threefold:

1. to review the conceptual issues concerning segmentation process of industrial markets

2. to develop a base of segmentation variables based on product attributes and on supplier needs

3. to report the findings of empirical research which was carried out to uncover the segments on bussines to bussines cardboard market and to compare it with previous research.

\section{Theory of market segmentation}

Market segmentation is considered as one of the crucial activities of contemporary marketing (Chernova et al. 2017). Some authors perceive it as important source of information for strategic decision making in the business and company resource allocation (Jain, 1997; Loštáková, 2005; Filip, Šimák, Kováč, 2011). Segmentation enables a business firm to define its marketing strategy and to allocate its resources across markets and product lines (Choffray, Lilien, 1980). Others (Kotler, Keller, 2008) connect it with the adoption of marketing conception oriented to identification and satisfaction of consumer needs, demands and desires through specification, creation, delivering and communication of specific value. Wind and Cardozo (1974) defined a market segment as a group of present or potential customers with some common characteristic that is relevant in explaining and predicting their response to a supplier's marketing stimuli. Segmentation reflects the reality regarding consumer needs, demands and behavior; it is rare to find only one type of customer, whose needs can be met by just one unified offer. On some markets, we are often confronted with the fact that every customer might be unique. In that case, it is financially and time-wise inefficient to develop specially tailored offers for every single customer. By appropriate categorization of customers into groups with similar needs, behavior and attributes, it is possible to significantly improve the efficiency of offers while maintaining bearable costs level. The segmentation is also an important tool for uncovering hidden possibilities and potentials for future development. According to (Harrison et al., 2010), this approach is important in commodities, where only insignificant differences 
between producers exist. Market segmentation is frequently appraised as an effective strategic marketing tool (Weinstein, 2006; Wind, 1978) and reflected in the well-known S-T-P conceptualization of the market segmentation process (Kotler, 2001). During the first stage (segmenting), customers are grouped by applying one or more base variables. This stage aims to group customers into segments with similar needs and buying behavior. In the second stage (targeting), decisions are made about where resources should be prioritized, whereas the final stage (positioning) focuses on the design of marketing mix programmes, that will match the requirements of customers in the targeted segments (Dibb, Simkin, 2001).

The desired outcome to reap the benefits of competitive advantage (Goller, Hogg, \& Kalafatis, 2002) i.e. gain market share and/or sell more. The outcome of market segmentation is finding groups with similar demands, but its goal is to gain competition advantage. Bonoma and Shapiro (1984) contended, that one of the major reasons for segmentation is "to provide the company with distinctive competitive advantage. "Segmentation is appropriate for those markets, where it is essential to combine individual customers or consumers into larger buying "units" to ensure marketing activity to be both cost-effective and manageable" (McDonald, Dunbar 2004). The level of standardization or individuality of customer approach is chosen by the companies individually. Up to date there is no clear instruction for the segmentation process. According to (McDonald and Dunbar, 2004) the segmentation process usually means following steps: market definition, identification of segmentation base appropriate for the given market, uncovering the segments and assembly of segments profile. Harris et. al (2010) recommends to realize the B2B market segmentation in following steps:

- Create individual segments for key customers

- Segment other customers traditionally

- Consider utilizing segmentation based on company firmographic data

- Apply segmentation based on needs where possible

- Use the methods of marketing research to identify customer needs

- If it is impossible to accurately determine customers' needs, consider the possibility of segmentation based on buying behavior

- Use cluster analysis in finding groups with similar needs or behavior

- Assign all existing or potential customers in to segments

- Implement proposed segmentation.

In the identification of segmentation variables company's (firmographic) data, which are readily and easily accessible, can be used. Abratt (1993) found that the three most common variables used to segment industrial markets are: geographic (87.5\% of the companies), demographic $(62.5 \%)$ and how often the product is used (62\%). The segments identified on firmographic data are the same for all, is argued (McDonald and Dunbar, 2004), so this approach does not offer competition advantage and does not lead to sufficiently homogenous company groups. Organizational and buyer characteristics do not provide the idea of these companies' expectations regarding product and expected services. Company data help to create the image of given market, but not idea about competitive offers.

The solution is the segmentation according to needs and demands. An examination of the traditional businessto-business segmentation variables used in the marketing literature highlights the lack of emphasis placed on customer as the prime segmentation variable (Mitchell, Wilson, 1998), (Filipova, 2016). According to findings Terho et al.(2015) there is the call for action concerning the development of effective segmentation schemes in business markets. They examined sales strategy dimensions and the segmentation was the only one with a direct impact on both market performance and salesperson performance. Paesbrugghe et al. (2017) emphasizes in their study that selling firms should approach their customers based on customers' buying styles and requirements.

The result of customer needs identification is the possibility to create targeted offers and not squander resources where it is not needed. To the customer group, who seek always the lowest price, standard offer can be given, sophisticated consulting services should be offered only to those customers who are interested in close coop- 
eration and long term relationship. While the benefits of that approach are obvious, implementation of that approach is problematic at best in the real world. The problems can be identified in information acquisition (who will provide the information regarding needs), instability of needs (for example in the connection with company strategy change and buyer preferences or in the connection to macroenvironment for example the change of demands during crisis). Segmentation by needs is perceived as ideal, because it fulfills the basic task of marketing, which is identification and satisfaction of customer needs, but it is also by far the most difficult considering realization and implementation.

Segmentation by buying behavior (Sharma and Lambert, 1994) is roughly in the middle between aforementioned processes and it is based on the uncovering of the company behavior patterns, from which purchasing motives can be deducted. It can be used when the company keeps customers records which enable to identify whether it is a regular customer consulting the purchase of new product variants in advance or one time customer taking advantage of momentarily favorable offer or using the suppliers' ability to quickly fulfill unexpected demand. Sharma and Lambert (1994) point out the importance of customer service requirements in segmentation due to possibility to create competitive advantage.

Wind and Cardozzo (1974) proposed the formation of macro segments in the first segmentation stage and after the selection of acceptable segments to continue in the second stage with microsegmentation. The output of from segmentation should include "key dependent variables on which firm can be assigned to segments (bases of segmentation) and set of independent variables which can provide better insight into the key characteristics of segment, i.e. descriptors of segment. Nested, multistep hierarchy model suggested by Shapiro and Bonoma (1984) identifies five general segmentation criteria groups, and recommend moving systematically from outer to inner nests, from firmographic through operating, purchasing approaches and situational criteria to personal characteristics of decisionmakers. According to the Shapiro and Bonoma (1984) it is up to the company and the given market whether in this "break-down" method all variables will be used on each level, which can be omitted and which added. Building-up approach, from Kotler (2001), sees the customers as individuals with different characteristics and recommends seeking similarities between them.

Freytag a Clarke (2001) and Lošt'áková (2011) emphasize the idea of segmentation by "kind of relationship, requested by customer", which is useful for the B2B market conditions. They basically differentiate transaction customers with the need of one time purchase and relationship customers who prefer long time cooperation.

\section{Data and methodology}

The methodology of this paper consists of following steps: 1. identification of product attributes and supplier demands, 2. surveying customers and data gathering, 3. data analysis and identification of customer clusters, 4. description of segments. Questionnaire was designed after consulting literature (Sharma and Lambert, 1994) and Gros et. al (2016). Customer needs and requirements were formulated by personal questioning of key account managers of cardboard producing companies and marketing, purchasing and logistic department employees from companies. Attributes were divided to the area of requirements in product attributes on corrugated cardboard and in requirements on suppliers' services attributess as follows:

\section{Product attributes}

1. Packaging quality (low scrap count, contracted attributes fulfillment)

2. Packaging cost (low price per piece)

3. Packaging material toughness (solidity, protective function)

4. Easy packaging manipulation (filling, transport, opening)

5. Marketing function for end customer (packaging design)

6. Low transportation costs (more products per pallet, light packaging)

7. Environmentally friendly packaging (recyclable, ecology footprint)

8. Information function (easy identification, traceability)

9. Special packaging construction (packaging is tailored to specific product needs) 
10. Special packaging or surface modification (hygienic, waterproof, rust protection)

Supplier services attributes

1. Lead time

2. Supply frequency

3. Invoice maturity time

4. Order fulfillment reliability

5. Consulting services (tailored packaging, packaging optimalization)

6. Supplier flexibility (in order volume change or lead time changes)

7. Brand or image of supplier

8. Low cost level

9. Broad assortment of standard packaging

10. Supplier references

To determine the importance of given attributes the respondents distributed 100 points between ten packaging attributes or ten supplier attributes according to their importance to the customers. The choice of constant-sum scale 100 points allocation (Aaker, 2004) secured the comparability of evaluators and lead to determination of mutual importance of criteria. These variables were measured on 0-100 scale. The electronic questionnaire was programmed in a way to facilitate the process of filling in by running count of point left to allocate and also this process secured that 100 point were always allocated. For the identification and addressing existing and most importantly potential customer's web based mail survey was used. The questionnaire was sent via mail to 73228 respondents, from which 215 were current customers of company ( $0,3 \%$ of respondents) and 73 013 potential customers. Potential customers were acquired from database Albertina (B2B company database) using export of chosen subjects according to economic activities classification (CZ-NACE). From the total number of economic subject in Czech Republic were chosen those having at least one listed economic activity corresponding to any of FEFCO sectors. This selection provided the list of 178099 subjects. From this list those who had listed at least one email address in the Albertina database, which was valid for 73013 subjects (41\% from total chosen). Respondents acquired from company (current customers) had always email address of person competent for packaging purchase. Respondents from general Albertina database had usually generic contact (info@examle.tld) or HR department in the case of larger companies. In the case of smaller companies or tradesmen direct contact was given. Completed questionnaires were returned in three weeks. The questionnaire itself was tailored as web application, using general HTML (HyperText Markup Language) language in combination with CSS (Cascading Style Sheets) on standard web platform LAMP (operation system Linux, web server Apache, MySQL database and script PHP). A total of 848 filled in questionnaires were collected. The reason for not filling in the questionnaire was with great probability the fact that many respondents do not use cardboard packaging and deleted the questionnaires from mail without providing the answer for first question which identified whether the respondent is able to give relevant data for the research.

IBM SPSS Statistics 19 (SPSS Inc., 2010) was used to evaluate the data acquired from the questionnaires. First, a general characteristic of whole respondent portfolio was performed. Principal components analysis on the basis of 20 input variables - customer needs in relation to packaging and to suppliers demands led to reduction to 7 factors, which were evaluated and interpreted by means of factor loadings. Only factors with eigenvalues greater than 1,0 were retained in the model. Then the orthogonal Varimax rotation was used to facilitate interpretation of the factors, Table 1 . Identified seven factors explain 57,3\% of total variance of 20 variables. 
Table 1. Rotated Component Matrix ${ }^{\mathrm{a}}$

\begin{tabular}{|c|c|c|c|c|c|c|c|}
\hline \multirow[b]{2}{*}{ Attributes } & \multicolumn{7}{|c|}{ Component } \\
\hline & F1 & $\mathrm{F} 2$ & F3 & F4 & F5 & F6 & F7 \\
\hline Identification of goods in supply chain & 0,693 & & & & & & \\
\hline Supplier affirmative references & 0,665 & & & & & & \\
\hline Special material or surface adjustment & 0,612 & 0,303 & & & & & \\
\hline Delivery frequency & 0,409 & & & & & & \\
\hline Marketing function for end customer & 0,390 & & & & & & \\
\hline Packaging ecology & 0,340 & & & & & & 0,301 \\
\hline Special packaging construction & & 0,824 & & & & & \\
\hline Consultancy service & & 0,553 & & & & & \\
\hline Supplier image & 0,332 & 0,465 & & & & & 0,308 \\
\hline Easy to manipulate & & & 0,710 & & & & \\
\hline Low transport cost & & & 0,579 & & & & \\
\hline Supplier flexibility & & 0,359 & 0,532 & & & & $-0,305$ \\
\hline Delivery reliability & & & & 0,836 & & & \\
\hline Packaging price & $-0,373$ & & $-0,380$ & $-0,520$ & & & \\
\hline Delivery date & & & & & 0,767 & & \\
\hline Low price level supplier & & & & $-0,498$ & $-0,650$ & & \\
\hline Payback time & 0,386 & & & & 0,439 & & $-0,302$ \\
\hline Packaging material durability & & & & & & $-0,884$ & \\
\hline Quality of packaging & & & & 0,384 & & 0,658 & \\
\hline Standard packaging big assortment & & & & & & & 0,752 \\
\hline
\end{tabular}

Extraction Method: Principal Component Analysis.

Rotation Method: Varimax with Kaiser Normalization.

Factor components of F1, „Total packaging“ describes complex demands of customer on the packaging function. The customer does not use the package only as protection, but examples for its other functions. Customers with high value of this factor demand identification of the package in supply chain, special surface treatment, appreciate its marketing function for final customers and its environmental friendliness. On the other hand price is not important. They demand supplier with positive references, high frequency of supplies and longer invoices payback time.

Factor components of F2 „Fitted packaging“ describes the companies' trend to emphasize the importance of special packaging construction (mainly tailoring to the product) or special material, surface treatment, consulting services needed to fulfill the customer's individual needs, brand and image of supplier and his flexibility. The customers with high value of this factors count among the most lucrative ones, they demand individual approach in their needs fulfillment

Factor components of F3 ,Transportation packaging "describes the companies" trend to accent logistical function of corrugate cardboard packaging: easy manipulation, low transportation costs and also supplier flexibility. For this the companies are willing to pay price premium.

Factor components of F4 "Reliability a quality regardless price" in the positive sense this factor describes the respondents' trend to accent high supplier reliability and packaging quality without regards to packaging unit price or low price level of suppler. In the negative sense it describes companies preferring price at the expense of packaging quality and supplier reliability.

Factor components of F5 „Immediately supply, delayed payment” describes the trend of short lead times with prolonged maturity of invoices and low sensitivity to low price level of supplier. The interpretation for this factor can lead to companies with high negative value of this factor, which are small, undemanding and saving companies seeking supplier with low price level, short lead time or long maturity of invoices). On the other hand, can the positive value of this factor be interpreted as the effort to acquire needed packaging in as little time as possible and then delay the payments? 
Factor components of F6 "Quality packaging without protective function" represents the trend, when respondents either prefer high quality packaging without protective function or durable packaging to protect the products without the accent to quality. On one side there are customers utilizing the corrugated cardboard packaging's other attributes and these accent quality, on the other side are customers using its protective qualities without regard to quality.

Factor components of F7 "Standard packaging"describes the customers preferring mainly broad standardized offer, partly of brand supplier and environmental friendliness of the packaging. On the other hand the maturity of invoices is not and issue for them, so is supplier flexibility. The company with high value of this factor is obviously one time purchaser of standard packaging, who also chooses brand or image and values the environmental friendly packaging.

The next step of the analysis was the clustering of customers into groups according to the factors. The analysis was carried out in IBM SPSS Statistics 19 (SPSS Inc., 2010) by Hierarchical Cluster Analysis with Ward Cluster Method, where Euclid distance squared was used to express the distance. The optimal number of segments was five, so as to get appropriate number of adequately sized segments, where the respondents will be similar to each other. If using four segments, one segment was too large (39\%), while when using six segments, two were unnecessarily small (9\%). The five derived segments were of similar size, only segment 3 has nearly $10 \%$ of respondents, segment 4 on the other hand nearly $30 \%$.

To describe these segments their profiling was carried out. In the first step according to seven factors on which basis were the segments created. In the next step the segments were profiled according to the original twenty variables. The Figure 1a describes the average count allocated to variables related to packaging attributes, on the Figure $1 \mathrm{~b}$ the average count related to demands on supplier.
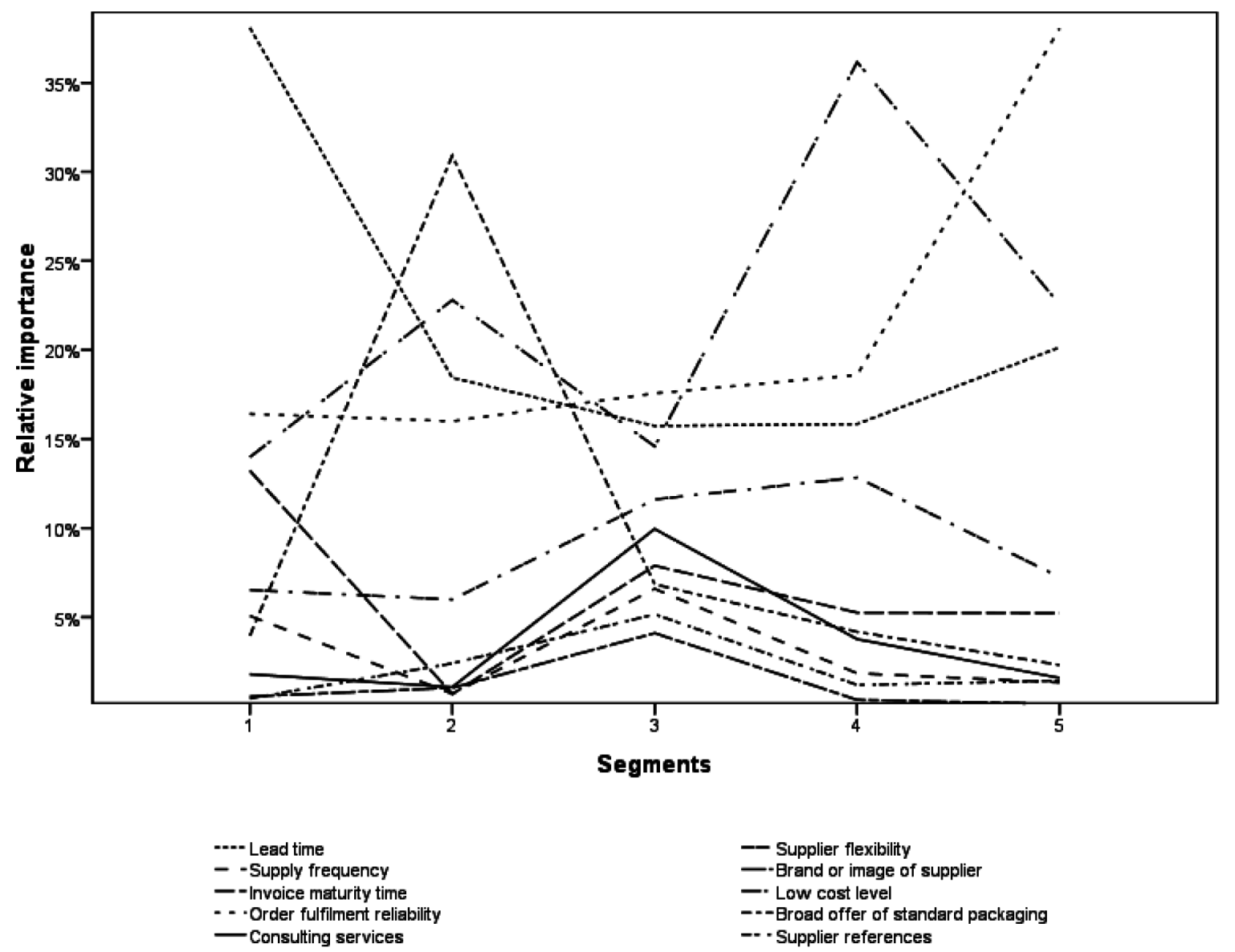

Fig. 1a. Average point count allocated to product attributes by respondents through five segments 

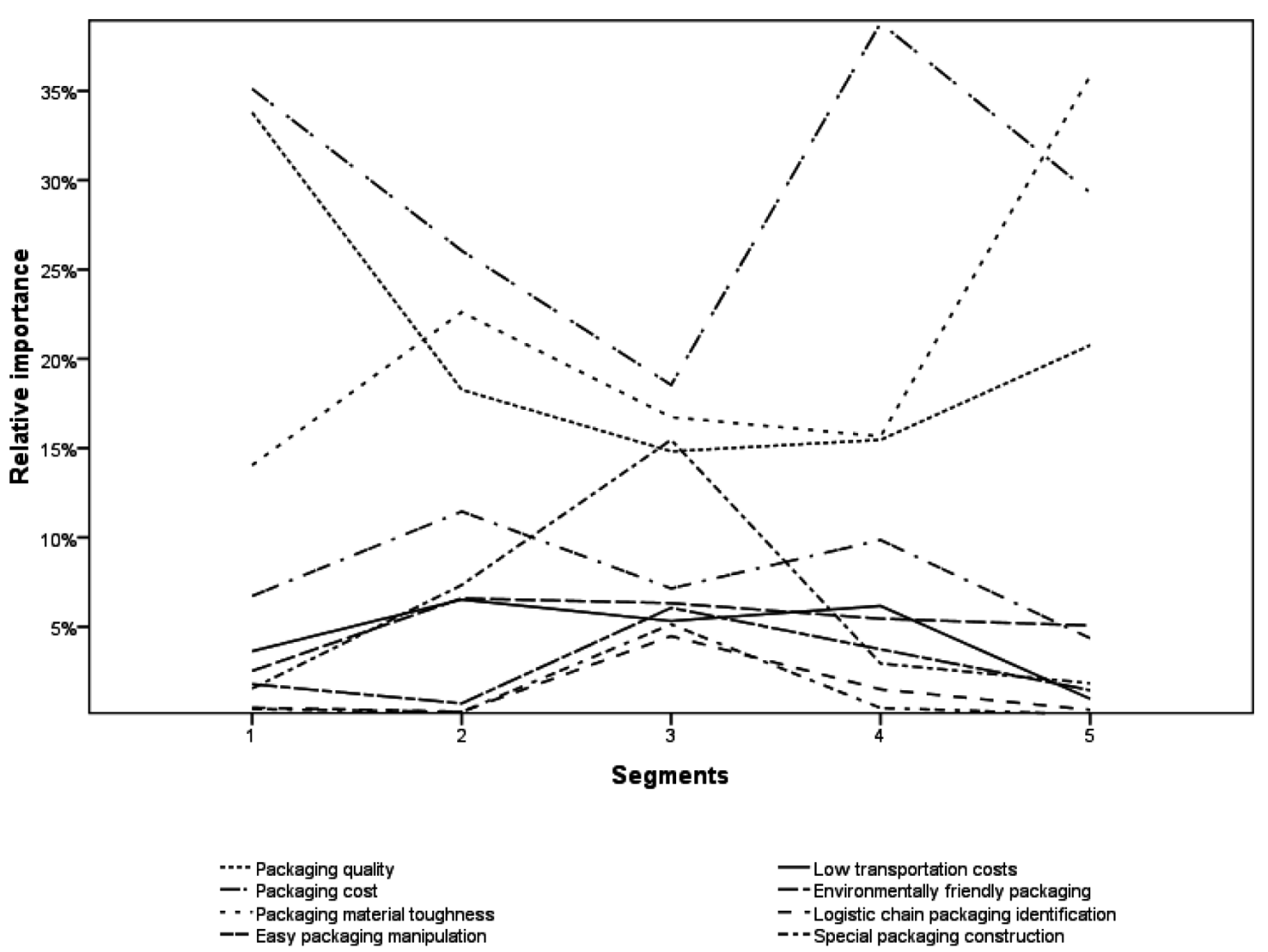

Fig. 1b Average point count allocated to demands on supplier by respondents through five segments

The profiles of acquired segments were then completed with the help of other questions which were to identify the respondent and facilitate the usability of segmentation in marketing strategy implementation. These were mainly the characteristics related to segment attractivity such as consumption volume, company size, turnover, branch according to FEFCO. The segments and their profiles are subject to further description.

Segment 1 - „Traditional, hard bargaining buyer“"

First segment represents roughly $20 \%$ of respondents, with above average emphasis on price and packaging quality, below average emphasis on environmental friendliness of packaging (Table 2). The most important the supplier attributes there are lead times and playback time are, on the other hand low total price is not a priority. Above average representation was in FEFCO sector "Beverages", in other segments the representation was average. From other characteristics the cooperation with multiple suppliers, central, nation-level supplier choice are typical. Also the long term contract (most frequently for 6 months up to one year) and higher frequency of supplies are typical. The demanded lead time importance is above average (2-3 days are most frequent) and longer invoice maturity. They also demand above average contact with supplier.

Table 2. Segment 1 profile

\begin{tabular}{|c|c|c|}
\hline & Significantly above average emphasis & Significantly below average emphasis \\
\hline Variables packaging & $\begin{array}{l}\text { Packaging price } \\
\text { Packaging quality }\end{array}$ & Environmental friendliness \\
\hline Variables supplier & $\begin{array}{l}\text { Supplier lead time } \\
\text { Invoice payback }\end{array}$ & Supplier low price level \\
\hline Factors & $\begin{array}{l}\text { Supply now, pay later } \\
\text { Quality packaging without protective function }\end{array}$ & \\
\hline
\end{tabular}




\section{Segment 2 - „Undemanding buyers of standard packaging“}

The second segment (Table 3) represents roughly 10\% respondents, being the least numerous segment, purchasing significantly below average packaging volumes, with its respondents having significantly below average turnovers and basic capital. The respondents emphasize broad offer of standard packaging, on the other they give low emphasis on supply frequency or invoice maturity.

Above average emphasis is on the easy manipulation with the packaging, environmental friendliness and low transportation costs of packaging - so they demand mainly the function side of packaging. Considering the FEFCO sectors the members of this segment are above averagely represented in sector "Electrical machinery, apparatus, equipment and accessories", on the other had below average represented in "Foodstuffs","Fresh foodsutffs, agricultural products", "Beverages", "Furniture, wooden and similar products", "Pottery, glassware and other non-metallic products" and "Metal and similar products". The members of this segment purchase low variety of packaging (most often 1-5 types) in small batches (either 0-100 or 100-1000 units). They change the packaging (and obviously its supplier) above averagely often, do not need consulting or packaging service. Most often these are companies of 1-5 employees.

Table 3.Segment 2 profile

\begin{tabular}{|l|l|l|}
\hline & \multicolumn{1}{|c|}{ Significantly above average emphasis } & \multicolumn{1}{c|}{ Significantly below average emphasis } \\
\hline Variables packaging & $\begin{array}{l}\text { Easy packaging manipulation } \\
\text { Environmental friendliness } \\
\text { Low transportation costs }\end{array}$ & $\begin{array}{l}\text { Supply frequency } \\
\text { Invoice maturity }\end{array}$ \\
\hline Variables supplier & Broad offer of standard packaging & Complex packaging \\
\hline Factors & $\begin{array}{l}\text { Standard packaging } \\
\text { Packaging for transport }\end{array}$ & \\
\hline
\end{tabular}

Segment 3 - „Demanding buyers of tailored packaging“

The third segment represents roughly $20 \%$ of respondents. It is the most demanding segment with low pressure to price but high demands to individual approach and services (Table 4). Companies in this segment have significantly above average turnovers and basic capitals. The respondents emphasize special packaging construction, special material or surface treatment, they accent environmental friendliness and marketing function of the packaging for final customer and last but not least traceability of the package in the supply chain. On the other hand they accent below average emphasis on unit price. They demand flexibility, supply frequency, reference and consulting services. Below average importance is given to low price level of supplier. In the FEFCO sectors we will find their above average representation in sector "'"Fresh foodsutffs, agricultural products" but also in "Soap, perfume, cosmetics, cleaning and cosmetic products”, „Ceramics, glassware and other non-metallic products“ and „Radio, TV, communicatios“. Companies in this sector purchase multiple types of packaging, are generally most optimistic regarding further purchasing volumes in next 3 years. They cooperate with more suppliers, the choice of supplier is above averagely frequent and centrally on international level.

They purchase packaging on auctions and contract frequently on long time basis. They prefer to order by email, demand high frequency of supplies, on the other hand the pressure on lead time is below average, 6-10 days is sufficient. They are distinguished by moderately below average demands on invoice maturity and significantly above average demands on consulting services before and during contracted period. Regarding packaging audit, they exhibit the highest interest. From all the segments environmental friendliness is the most important. They are above averagely represented by stock companies with high employee number. 
Table 4. Segment 3 profile

\begin{tabular}{|l|l|l|}
\hline & \multicolumn{1}{|c|}{ Significantly above average emphasis } & \multicolumn{1}{c|}{ Significantly below average emphasis } \\
\hline Variables packaging & $\begin{array}{l}\text { Special packaging construction } \\
\text { Environmental friendliness } \\
\text { Marketing function } \\
\text { Special packaging material or special } \\
\text { surface treatment } \\
\text { Supply chain traceability }\end{array}$ & Packaging unit price \\
\hline Variables supplier & $\begin{array}{l}\text { Supplier flexibility } \\
\text { Supplier consulting services } \\
\text { Supply frequency } \\
\text { Supplier references } \\
\text { Supplier brand or image }\end{array}$ & Supplier low price level \\
\hline Factors & $\begin{array}{l}\text { Complex packaging } \\
\text { Tailored packaging }\end{array}$ & \\
\hline
\end{tabular}

Segment 4 - „Saving buyer“

Fourth segment represents roughly $30 \%$ of respondents, being the largest. The respondents are distinguished by highest pressure on unit price and generally low price level of the supplier. As it is common in these saving segments, not only the segment is the largest regarding the customer count, but its customers have highest average packaging consumption, twice the number compared to the total average. Aside from the high pressure on price, they demand easy manipulation with the package and low transportation costs, on the supplier side they demand flexibility (Table 5). In FEFCO sectors, the above average count of the respondents if sound in sectors "Foodstuffs", "Textile, clothing, leather goods" and "Metal, metal processing".

Customers use above average number of packaging types, internet is the main tool of new supplier finding. They are content with longer lead times but pay mature invoices less frequently.

Table 5. Segment 4 profile

\begin{tabular}{|l|l|l|}
\hline & \multicolumn{1}{|c|}{ Significantly above average emphasis } & \multicolumn{1}{c|}{ Significantly below average emphasis } \\
\hline Variables packaging & $\begin{array}{l}\text { Packaging unit price } \\
\text { Easy packaging manipulation } \\
\text { Low transportation costs }\end{array}$ & $\begin{array}{l}\text { Supplier low price level } \\
\text { Supplier flexibility }\end{array}$ \\
\hline Variables supplier & $\begin{array}{l}\text { Packaging for transport } \\
\text { Quality package without protective function }\end{array}$ & $\begin{array}{l}\text { Supply now, pay later } \\
\text { Reliability and quality without regards to price }\end{array}$ \\
\hline Factors
\end{tabular}

Segment 5 - „Conservative buyer of traditional packaging“

Fifth segment (Table 6) represents roughly $20 \%$ of respondents. Its members value the traditional protective function of packaging from corrugated cardboard and emphasize the toughness of the packaging. On the other hand they emphasize less than average the easy manipulation and low transportation costs. From the supplier they demand reliability. Because of their average yearly unit consumption being below average they hold the same position regarding turnover and basic capital.

Their representation in FEFCO sectors was found in "Furniture, wooden and similar products", "Paper, printing material", "Chemicals and similar products" and "Sport goods, toys". The customers buy lower number of packaging types (max. 20), order also smaller batches than average (regarding units) and most often cooperate with one or two suppliers with whom are above averagely satisfied. They also value references and recommendations in new supplier choice. They prefer ordering by phone or in person. They are also undemanding in regarding frequency of supply (few times a year) and their lead time most often over 11 days. They pay their invoices due time, contact with supplier is demanded once a year or they contact the supplier when they need. Packaging change takes place only after a long time, most often after over 3 years, have accurate packaging specifications and do not demand consulting or packaging audit (Table 6). Most often these are companies of 1-5 employees or tradesmen. 
Table 6. Segment 5 profile

\begin{tabular}{|l|l|l|}
\hline & \multicolumn{1}{|c|}{ Significantly above average emphasis } & \multicolumn{1}{c|}{ Significantly below average emphasis } \\
\hline Variables packaging & Packaging toughness & $\begin{array}{l}\text { Easy packaging manipulation } \\
\text { Low transportation costs }\end{array}$ \\
\hline Variables supplier & Supplier reliability & \\
\hline Factors & Reliability and quality without regards to price & \\
\hline
\end{tabular}

\section{Comparison of results}

The results of two researches of B2B corrugated cardboard market segmentation, carried out in 2010 and 2015 lead to following conclusions:

The form of electronic questioning focused primarily on potential customers using commonly accessible addresses of companies has significantly broadened the portfolio of respondents whose results entered the segmentation process ( 840 in comparison with 100 respondents). The average count of respondents whose answers were used in segment profile compilation is 170 compared to 25 . The acquisition of sufficient number of answers on B2B markets is a challenge according to Fill and McKee (2011).

The data acquired in both phases of research were processed using the same method, however different the method of segmentation basis compilation, i.e. data used in factor and cluster analysis and following segment profile creation. In the second phase of the project the segmentation base was consisted of both the customers' package attribute demands and demands on the supplier, which are fundamental on the B2B market. Other characteristics were used in segment profile compilation. Firmographic data such as branch of industry, turnover, packaging expenses etc. were used so as to ease the phase of segment evaluation and choice.

In spite of differently named factors and segments, there has been found a match in three segments: "Planning customers" from the first study and „Demanding buyers of tailored packaging“, "Unassuming consumers" and "Undemanding buyers of standard packaging" and "The occasional buyers and „Saving buyer". As an example of specific strategy, the use of internet market where customers from segment "Undemanding buyers of standard packaging” and „Saving buyer“ choose products from broad range of standard packaging, which enables lowering the service costs of this not very attractive segment, can be given. „Demanding buyers of tailored packaging" will continue to demand individual approach and tailored solution based not only on their knowledge of package demands but also based on the demands of other participants in their supply chain.

The interpretation of acquired factors and segments is subjective to some extent. As stated by McDonald and Dunbar (2004), the choice of segmentation base and segment profile compilation is an iterative approach and is connected with the purpose which was the segmentation carried out for.

In present Czech economy undergoes turbulent period of regrowth after the reccession and this fact makes all the statements regarding groups of companies more questionable than usual. Described segments are a good basis for further market development survey, which will inevitably lead to its update. Recently, Thomas (2016) propose to include into segmentation process also the customer's customer and so on, in a multistage market segmentation structure. This approach can be useful in the corrugated cardboard industry, where the packaging is manipulated in retail sector or can produce value to end customer.

\section{Conclusions}

Nearly 30 years ago, Shapiro and Bonoma (1984) noted that segmentation was used, more as a way of explaining and understanding marketing outcomes rather than as an important component of planning for the future. This article described the process of two researches conducted in order to identify and compile profiles of found segments so as to enable the design of targeted marketing based on customer needs on product and on supplier. 
Applicability of results is limited to specific corrugated cardboard users market. From the view of corrugated cardboard packaging producers the proposed model has its use as helpful tool in service provision development and new customers' acquisition.

Today's relevant segments are not only industry-specific; they are probably company-specific as well. And those segments will change constantly so requiring revision and correction with new data on real behaviors.

\section{References}

Aaker, A. D., Kumar, V., Day, G.S. 2004. Marketing research. $8^{\text {th }}$ Edition. New York: Published by John Wiley\&Sons Inc.

Abratt, R. 1993. Market Segmentation Practices of Industrial Marketers. Industrial Marketing Management, 22: 79-84. http://doi. org/10.1016/0019-8501(93)90033-4

Bonoma, T. V, Shapiro, B. P.;\&. 1984: Evaluating Market Segmentation Approaches. Industrial Marketing Management, 13:258-264_ https://doi.org/10.1016/0019-8501(84)90021-X

Chernova, V. Y.; Zobov, A. M.; Starostin, V. S.; Butkovskaya, G. V. 2017. Sustainable marketing communication strategies of Russian companies under the import substitution policy, Entrepreneurship and Sustainability Issues 5(2): 223-230. https://doi.org/10.9770/ jesi.2017.5.2(5)

Choffray J.M., Lilien, G.L. 1980. Industrial marketing Segmentation by the Structure of the Purchasing Process, .Industrial Marketing Management 9: 331-342. https://doi.org/10.1016/0019-8501(80)90049-8

Dibb, S., Simkin, L. 2001. Market Segmentation: Diagnosing and Treating the Barriers. Industrial Marketing Management, 30(8), 609625. http://doi.org/10.1016/S0019-8501(99)00127-3

FEFCO Industry Statistics (2006-2014). Retrieved from: wwwhtpps//fefco.org/media-publications/industry-statistics.

Fabuš, M. 2017. Current development of business environment in Slovakia and Czech Republic, Entrepreneurship and Sustainability Issues 5(1): 127-137. https://doi.org/10.9770/jesi.2017.5.1(10)

Filip, S., Šimák, L., Kováč, M. 2011. Risk Management.Bratislava.Sprint dva.s.199.ISBN 978-80-89393-49-7.

Filipová, L. 2016. Customer research of non-bank entities. MEST journal 4(2): 94-102. http://doi.org/10.10.12709/mest

Fill, Ch. \& McKee, S. 2011. Business Marketing Face to Face: The Theory and Practice of B2B. Mesa, AZ, USA: Goodfellow Publishers Limited, 2011. ProQuest ebrary.

Freytag, P.V. \& Clarke, A.C. 2001 Business to business market segmentation. Industrial Marketing Management 30: 473-86. https:// doi.org/10.1016/S0019-8501(99)00103-0

Goller, S.; Hogg, A.; Kalafatis, S. P. 2002: A new research agenda for business segmentation. European Journal of Marketing 36(1): 252-271. https://doi.org/10.1108/03090560210412782

Gros, I. et al. 2016. Velká kniha logistiky. Praha: Published by Vysoká škola chemicko-technologická.

Grosová, S. \& Gros, I.; \& Císařová, M. 2011. B2B segmentation as a Tool for Marketing and Logistic Strategy Formulation. Intellectual Economics, 5(1): 54-64.

Harrison, M. \& Hague, P. \& Hague, N. 2010: Why is Business -to Business Marketing Special? B2B International. Retrieved from: htpps://b2binternational.com/publications/b2b-marketing/

Jain, S.C. 1997. Marketing Planning\&Strategy. Cincinnati, Ohio: Published by South Western College Publishing.

Kotler, P.; \& Keller, K. L. 2008: Marketing management. 13th Ed., New Jersey. Published by Pearson Prentice Hall

Loštáková, H. 2005: B-to-B marketing: Strategická marketingová analýza pro vytváření tržních př́ležitostí; Praha, Published by Professional Publishing.

Loštáková, H. 2009. Diferencované ř́zeni vztahů se zákazníky. Praha: Published by Grada Publishing

McDonald, M., Dunbar, I. 2004. Market Segmentation. Oxford: Published by Elsevier Ltd. 
Mitchell, V.V.;\& Wilson, D.F.1998. Balancing Theory and Practice: A Reappraisal of Business-to-Business Segmentation. Industrial Marketing Management 27, 429-445 https://doi.org/10.1016/S0019-8501(98)00002-9

Oganisjana, K.; Svirina, A.; Surikova, S.; Grīnberga-Zālīte, G.; Kozlovskis, K. 2017. Engaging universities in social innovation research for understanding sustainability issues, Entrepreneurship and Sustainability Issues 5(1): 9-22._https://doi.org/10.9770/jesi.2017.5.1(1)

Paesbrugghe, B., Rangarajan, D., Sharma, A., Syam, N., Jha, S. 2017. Purchasing-driven sales: Matching sales strategies to the evolution of the purchasing function. Industrial Marketing Management 62(2017) 171-184. https://doi.org/10.1016/j.indmarman.2016.09.002

Sharma, A.;\&, Lambert, D. M. 1994: Segmentation of markets based on customer service. International Journal of Physical Distribution \& Logistics Management, 24 (4), 50-58. http://doi10.1108/EUM0000000000369

Ślusarczyk, B.; Kot, S. 2018. Solution for sustainable development: provisions limiting the consumption of disposable plastic carrier bags in Poland, Journal of Security and Sustainability Issues 7(3): 449-458._https://doi.org/10.9770/jssi.2018.7.3(7)

SME classification https://ec.europa.eu/growth/smes

Terho, H., Eggert, A., Haas, A., Ulaga, W.2016 How sales strategy translates into performance: The role of salesperson customer orientation and value-based selling. Industrial Marketing Management 45 (2015) 12-21. https://doi.org/10.1016/j.indmarman.2015.02.017

Thomas, R.J. 2016. Multistage market segmentation: an exploration of B2B alignment. Journal of Business \&Industrial Marketing, 31,821-834. https://doi.org/10.1108/JBIM-12-2015-0245

Weinstein, A. A. 2006. Strategic framework for defining and segmenting markets. Journal of Strategic Marketing 14: 115-127 https:// doi.org/10.1080/09652540600659665

Wind, Y.;\& Cardozo, R. N. 1974. Industrial Market Segmentation. Industrial Market Management 3 (3): 153-165. http://doi. org/10.1016/0019-8501(74)90025-X

Wind, Y.1978. Issues and Advances in Segmentation Research. Journal of Marketing Research. 15(3):317-337. http://doi. org/10.2307/315058

Žáček, V. 2010. Průmyslový marketing. Praha, Published by: České vysoké učení technické v Praze

Vladimír Kubeš is a CEO of INTERLIGNUM a.s. and INTERMONT s.r.o which are companies producing furniture and selling their products in the Czech Republic, Slovakia and Poland. In the research he is interested in the strategy of customer relationship management in the field of furniture and long term consumption goods. He graduated the Technical University in Zvolen, Slovakia in the field of Economy and Management of Wood Industry and got an Engineer Degree, he got a Ph.D. in the University of Chemistry and Technology in Prague, Faculty of Chemical Engineering, Department of Economics and Management.

ORCID ID: orcid.org/0000-0003-4544-7140

Stanislava Grosová is Assoc. Prof. University of Chemistry and Technology, Department of Economics and Management. She teaches Strategic Marketing, Marketing Research and Management and Organisation. Her professional interests are mainly in the fields of B2B marketing, consumer behavior and distribution with respect to food product. She has published in the Czech Journal of Food Sciences, Foresight, Intellectual Economics, and has presented papers on conferences.

ORCID ID: orcid.org 0000-0002-9252-800X

Pavel Weber graduated at the University of Chemical Technology in Prage in 2012 and has got Ing. Degree in the field of Economics and Management of Chemical and Food Industry. He is doctoral student at ICT Prague and CEO of Blue Ghost, s.r.o. which produces web applications for companies in the research he is interested in the field of Bussines Market Segmentation.

ORCID ID: orcid.org/0000-0002-6975-7074 